УДК.330.15

DOI: 10.31891/2307-5740-2021-300-6-24

OKSANA YELISEYEVA, P. PROSHKINA

Oles Honchar Dnipro National University

\title{
METHODOLOGICAL ASPECTS OF ESTIMATING THE INFLUENCE OF THE ENVIRONMENTAL COMPONENT ON THE LIFE QUALITY OF UKRAINE POPULATION
}

\begin{abstract}
This article examines the impact of the environmental component on the life quality of the population by comparing the impact of economic and environmental indicators, also proposed an Eco-index, calculated by a multivariate average, based on indicators selected taking into account the characteristics of Ukraine. The ecological management of the Ukarine was studied comparing to the management on EU countries. A rating of the region of Ukraine was built according to the index of environmental development on the basis of the multivariate average method. Also, the main differences were identified between the environmental policy of Ukraine and European countries. In addition, the dynamics of the main environmental and economic indicators of Ukraine for the period 2014-2020 was studied.

Keywords: life quality, expences, ecological component, index, management.
\end{abstract}

ЄЛІСЕЕВА О. К. ORCID ID: 0000-0003-4907-5700 e-mail: ok17_5@ukr.net

ПРОШКІНА П. М. e-mail: pr@gmail.com Дніпровського національного університету ім. О. Гончара

\section{МЕТОДОЛОГІЧНІ АСПЕКТИ ОЦНЮВАННЯ ВПЛИВУ ЕКОЛОГІЧНОЇ КОМПОНЕНТІ НА ЯКІСТЬ ЖИТТЯ НАСЕЛЕННЯ УКРАЇНИ}

\begin{abstract}
У статті досліджується вплив екологічної складової на якість життя населення шляхом порівняння впливу економічних та екологічних показників, також запропоновано Екоіндекс, що розраховується за багатовимірним середнім, на основі показників, обраних з урахуванням особливостей України. Екологічний менеджмент України вивчався у порівнянні з менеджментом у країнах ЄС. Побудовано рейтинг регіону України за індексом екологічного розвитку на основі багатовимірного середнього методу. Також були визначені основні відмінності між екологічною політикою України та європейських країн. Крім того, досліджено динаміку основних еколого-економічних показників України за період 2014-2020 років.

Ключові слова: якість життя, витрати, екологічна складова, індекс, управління.
\end{abstract}

Introduction. Nowadays, when pandemic is a part of everybody's life, more than ever, scientists are paying attention to the ecological development of countries. Many famous scientists, in particular, such as V. Bugaev, G. Glukhanova, A. Lagutin, studied the influence of environmental factors on demographic processes in the country and the quality of life of the population. In scientific papers of the above scientists, this issue was studied by comparing the experience of Ukraine and the EU countries, and demographic processes were taken as the basis for the estimating quality of life. This article examines the impact of the environmental component on the life quality of the population by comparing the impact of economic and environmental indicators, also proposed an Eco-index, calculated by a multivariate average, based on indicators selected taking into account the characteristics of Ukraine.

Environmental problems play a significant role in everyone's life. However, at a time when some countries continue to develop their own eco-reforms, others remain on the edge of life and death because of the state of ecology. So, for example, the problem of the population's access to central water utilities and drinking water is a global problem. In countries such as Ethiopia, Nigeria, Somalia, India, a significant part of the population (about 60 million people) does not have direct access to clean drinking water. However, these countries are not economically developed and hold almost the last positions in the ratings of GDP, happiness index, etc. A country like China, however, which amazes the whole world with the rapidity of economic development and holds a leading place in the world in terms of GDP, is also experiencing problems with access to clean drinking water for the population, precisely because of the rapid development of industry [3]. This is demonstrated by the fact that economic development and a high level of the country's GDP do not guarantee a high level of development of the ecological sphere and the quality of life of the population.

The purpose of this article is to assess the impact of environmental development on the life quality of the population of Ukraine.

The study on the scientific paper was based on statistical and analytical methods.

Based on the results of the work, a rating of the region of Ukraine was built according to the index of environmental development on the basis of the multivariate average method. When calculating the average, the following indicators were used: expenses for environmental protection, capital investments for environmental protection, the volume of waste generated, the volume of recycled waste and emissions of pollutants into the atmospheric air of Ukraine. Also, the main differences were identified between the environmental policy of Ukraine 
and European countries. In addition, the dynamics of the main environmental and economic indicators of Ukraine for the period 2014-2020 was studied.

The main factor in determining the standard of living of the population is the level of longevity, and the state of the environment certainly affects this indicator. An analysis of scientific works and studies on this problem shows that among the factors that determine the level of morbidity, the state of the environment is about $20 \%$, while the dependence on the level of development of the health care system is only $7-12 \%[3,6]$.

Scientific studies conducted by the World Health Organization (WHO) have revealed a strong connection between environmental pollution and the incidence of prematurity, malformations in children and chromosomal diseases, allergic pathology, anemias, mental retardation and behavioral abnormalities in children, and their physical development. Children living in areas of ecological disaster are diagnosed with congenital malformations, recurrent bronchitis, allergic diseases, decreased intelligence quotient (IQ), bronchial asthma, neuropsychiatric diseases, oncopathology, etc. [11].

The WHO European Center for Environment and Health to assess the relationship between the state of the environment and public health recommends the following main groups of indicators: health status (mortality, morbidity, prevalence of diseases); physical environment (status and impact indicators) - housing, quality of drinking water and atmospheric air, radiation, noise; working conditions (the impact of factors on the body); health protection (regulatory assurance of food quality); health services [11].

Considering the problem of the influence of environmental factors on the health of the population within the framework of a general socio-ecological approach, one cannot but take into account the real state of public consciousness in the field of environmental problems. According to the generalized results of expert surveys of recent years, experts considered the following environmental risks to be the most urgent for the population of large cities: the quality of drinking water (60-70\% of experts); climatic features of the rock (30-40\%); food safety (50-55\%); sanitary condition of the habitat (40-45\%); condition of water resources (rivers, lakes) - 60-65\%: air pollution $(65-70 \%)$; soil pollution (55-60\%); increased noise level (30-45\%); the aesthetic state of the environment (40-50\%) etc. [4].

Regarding the influence of environmental factors on the quality of life, the analytical center of the New Economics Foundation created the World Happiness Index in 2006, which, unlike other, more popular indices, is distinguished by the presence of an indicator of the efficiency of the use of natural resources. The authors of the rating emphasize that in those countries where the emphasis is on the development of production, and with it on economic growth, people, as a rule, do not become happier, since the economic theories adhered to by the authorities of these states have nothing to do with life. real people. According to this index, countries that have achieved a sufficiently high economic growth occupy almost the last positions, precisely because of the ineffective use of natural resources. For example, the United States ranks 108, Germany - 49, and Ukraine - 70.

Regarding the determination of the state of the environment, the main indicator is the amount of waste, because it is the pollution of the environment, in particular the aquatic environment, that is associated with the problem of ecology of countries. The dynamics of change in the amount of waste is shown in Fig. 1.

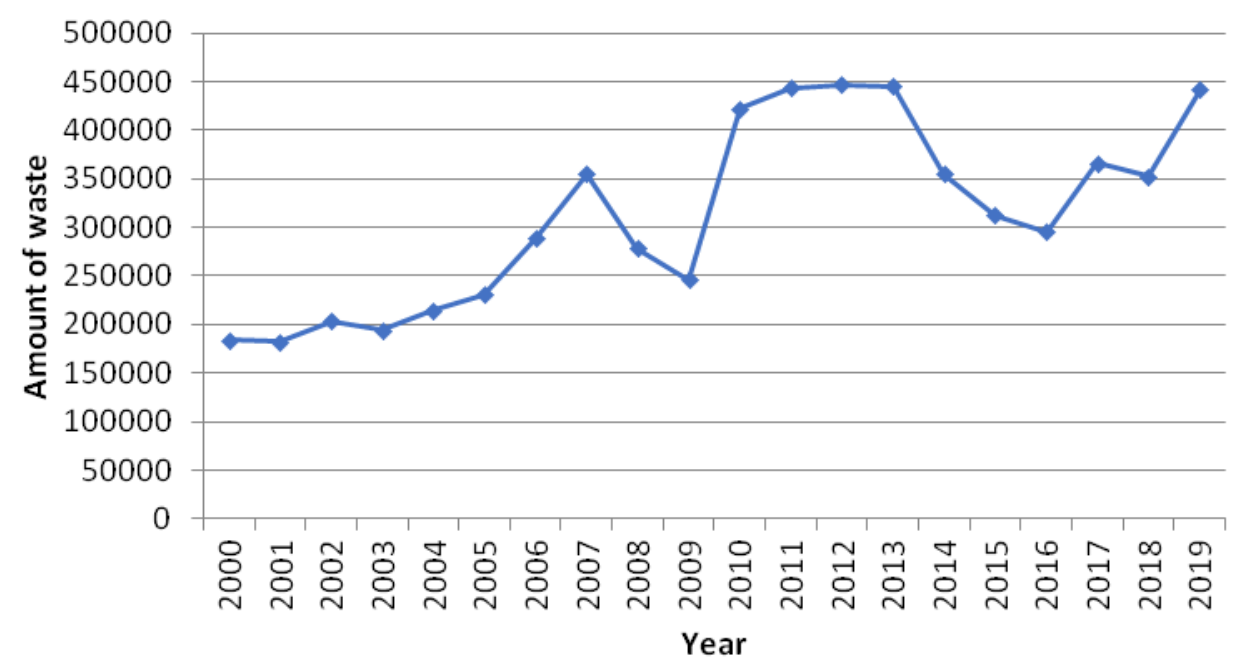

Fig. 1. Dynamics of changes in the amount of waste in Ukraine in the period 2000-2019

* constructed by the author on the basis of data [1]

The biggest role in environmental pollution is played by industrial waste, which means that today environmental security is closely linked to the economic development of the country. Thus, examining this relationship in the period 2000-2019, it was found that the correlation index of the amount of waste with GDP is 0.62 . Instead, the correlation index of the amount of waste with the amount of application is -0.62 , which indicates an inverse connection.

Consequently, the state of morbidity of the population or the danger to its health is closely related to the 
volume of industrial production, the state of pollution of certain natural areas, hazardous man-made industries of the giants of the industry, which also affects planetary climate change - a decrease in the ozone layer and a warming of the climate; security is one of the most pressing and important issues for every country.

This raises the question of determining the dynamics of development and the state of the environment of countries.

The Yale Center for Environmental Policy and Law, in conjunction with Columbia University and the World Economic Forum, publishes an annual report on the results of the Environmental Performance Index. This index is the main method for determining the state of the environment in the countries of the world.

The Environmental Performance Index (EPI) measures the state of sustainable development around the world. Using 32 performance metrics across 11 problem categories, the EPI ranks 180 countries on environmental health and ecosystem resilience. These indicators provide a national assessment of how close countries are to established environmental policy goals. EPI offers a scorecard that identifies leaders and laggards in environmental performance and provides practical guidance for countries as they strive towards a sustainable future.

Countries are assessed for two groups of environmental status (40\%) and ecosystem resilience $(60 \%)$; each group has several categories such as water quality, air quality, forest area, climate change and energy, etc.

However, there is also criticism from some scholars regarding the methodology of this index. The EPI methodology has been criticized for its arbitrary choice of indicators that could lead to bias, and its poor performance as an indicator of environmental sustainability. Additional criticism focused on the EPI's lack of specific policy proposals and the bias in the index for weighing data-deficient countries, which has led to an underestimation of environmental progress in developing countries.

According to the latest data in 2020, Ukraine ranks 60th in the world according to this rating and 4th place among post-Soviet countries, behind Belarus, Armenia and Russia.

The Sustainability Index was developed for 180 countries, therefore it does not take into account the specific features of each individual country. Therefore, for Ukraine, the author has developed his own Eco-index by ranking the regions of Ukraine on the basis of a complex integral indicator. By analyzing the main economic, environmental and social indicators of Ukraine for the period 2014-2020, identifying patterns and peculiarities of the country, 5 main indicators were identified, which were used as the basis for the calculated integral indicator. Among them: expenses for environmental protection, capital investments for environmental protection, the volume of waste generated, the volume of recycled waste and emissions of pollutants into the atmospheric air of Ukraine. The results of the ranking are shown in Fig. 2.

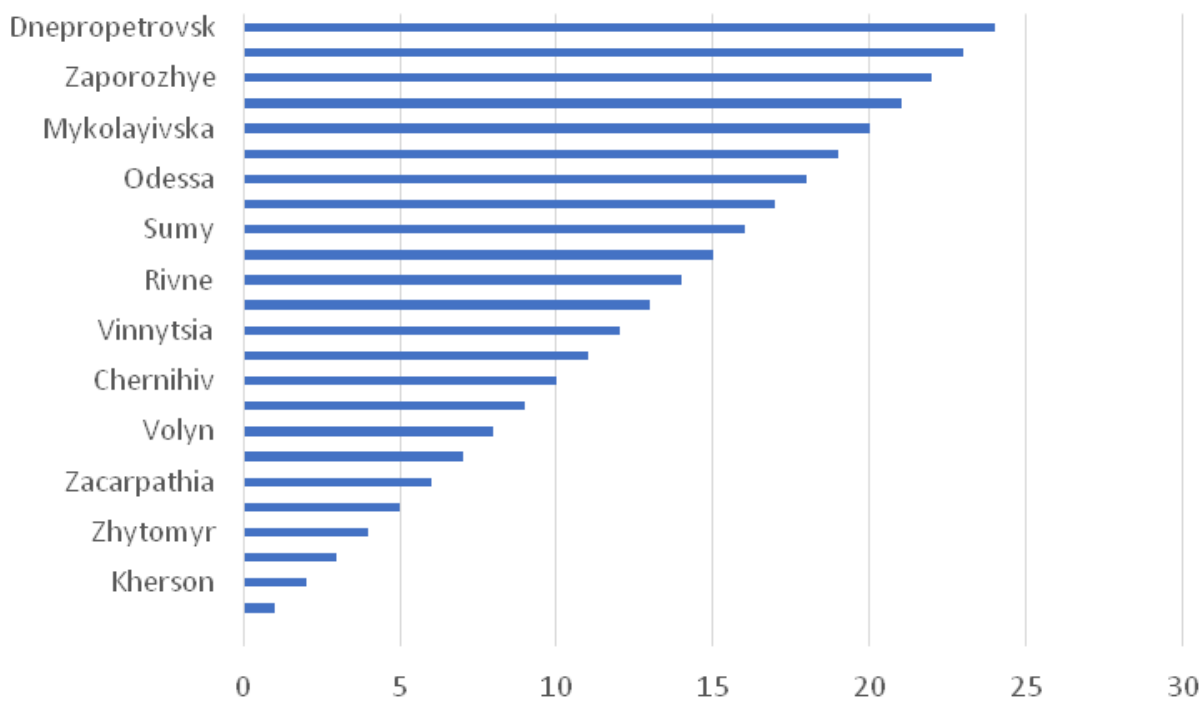

Fig. 2. Rating of Ukrainian regions in terms of economic and environmental indicators in 2020

* built by the author on the basis of data [1]

The results obtained were comparable to the level of GRP in each region and it should be noted that most regions with a high level of GRP are in the last positions in this rating. So, for example, the Dnipropetrovsk region is the first in terms of GRP and the last in the rating of environmental development. This pattern is caused by the fact that economic development entails the development of industry, which in turn implies an increase in the level of environmental pollution. Kherson region ranks second in the ranking and has the largest volume of recycled waste $82 \%$. The Transcarpathian region is the last in this indicator, since it utilizes only about $0.5 \%$ of the generated waste.

In such conditions, the question of carrying out reforms in the country's environmental policy arises. However, the management process in the environmental sphere is multi-level and must be carried out in an integrated manner.

In the modern world, in the context of significant climatic changes, one can notice structural changes in the 
budgets of countries around the world due to an increase in the share of spending on environmental protection. Elimination of pollution and waste disposal are the key items of expenditure. Consequently, it becomes relevant to study the process and ways of management in this area.

First, it is necessary to define the concept of environmental protection and its own management. Environmental protection is a set of measures aimed at preventing, reducing or eliminating pollution, other types of harmful effects of economic and other activities on the environment, when providing services or using products, as well as preserving biodiversity and the habitat [1].

Management is a purposeful influence on an organized system, ensuring the preservation of its certain structure, maintaining the regime and goals of activity [3]. However, in the context of modernization, the term of management in almost all areas of activity was replaced by the term "management", except for those cases when it comes to management in state bodies, the term "public administration" or administration is used. In the broadest sense of the word "management" is the ability to achieve set goals using labor, intelligence, motives of people's behavior. Despite the fact that the concept of management is broader than the concept of management, in this work they are used as equivalent.

When studying environmental cost management, it is important to determine the structure, purpose and object of environmental management.

The general goal of environmental management is to achieve the desired, possible and necessary state of the controlled system - the environmental sphere.

The organizational structure of management is a set of management links located in strict subordination, providing the relationship between the management and the controlled systems.

The object of management is the ecological sphere, the main element of which is the relationship for the preservation (reproduction) of individual elements of the natural environment or natural complexes in general.

It should also be noted that in the management system, the ecological sphere is interpreted not only as the environment, the functioning of which is conditioned by environmental laws, but from the point of view of economic relations, as a sphere of environmental and resource-saving labor. Accordingly, one should distinguish: the natural resource sphere, as the sphere of ecologically oriented (resource-saving) labor in material production, and the environmental sphere, as the ecological sphere itself.

A key place in the system of state bodies for managing natural resources and environmental protection is occupied by the Ministry of Environmental Protection and Nuclear Safety of Ukraine of the regulation approved by the Decree of the President of Ukraine dated 10.02. 1995 [4] In the system of the Ministry of Environmental Safety of Ukraine, the functions of state control are assigned to the State Ecological Inspectorate. The main bodies in this area are the State Department for Environmental Protection and the State Environmental Inspectorate.

As for the current state of ecology in Ukraine and the world as a whole, analysts give negative forecasts, however, they note that when changes in environmental policy are made, the dynamics can be changed to positive. However, carrying out environmental activities requires significant financial costs. For example, the countries of the European Union annually spend about $2 \%$ of GDP on environmental protection. And these amounts are gradually increasing.

In Ukraine, there is a dynamics of growth in the amount of spending on environmental protection (Fig. 3), but the amount is only about $0.5 \%$ of the total state budget.

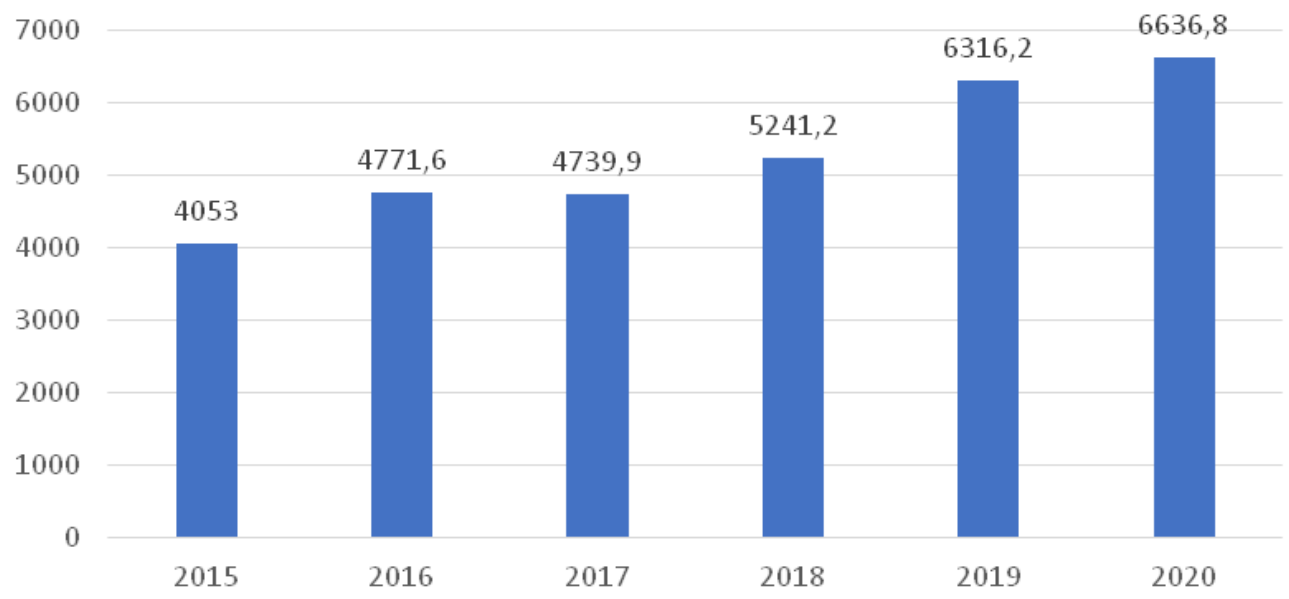

Fig. 3. Dynamics of the amount of expenditures for the protection of the natural environment, million UAH * built by the author on the basis of data [1]

The growth of inflation also has a negative impact, which significantly devalues the amount of expenditures, for example, in 2016 the actual amount was 4771.6 million UAH ( $0.72 \%$ of the state budget $)$, and in $2020-6636.8(0.53 \%$ of the state budget). $)$, however, given the growing inflation index, spending on environmental protection in 2020 is lower than in 2016. It is also important to note that although the 2020 pandemic had negative consequences for economic development, in particular for Ukraine, analysts identified an improvement 
in the environmental situation in the world through the COVID-19 pandemic, namely, a significant decrease in the amount of pollution and waste.

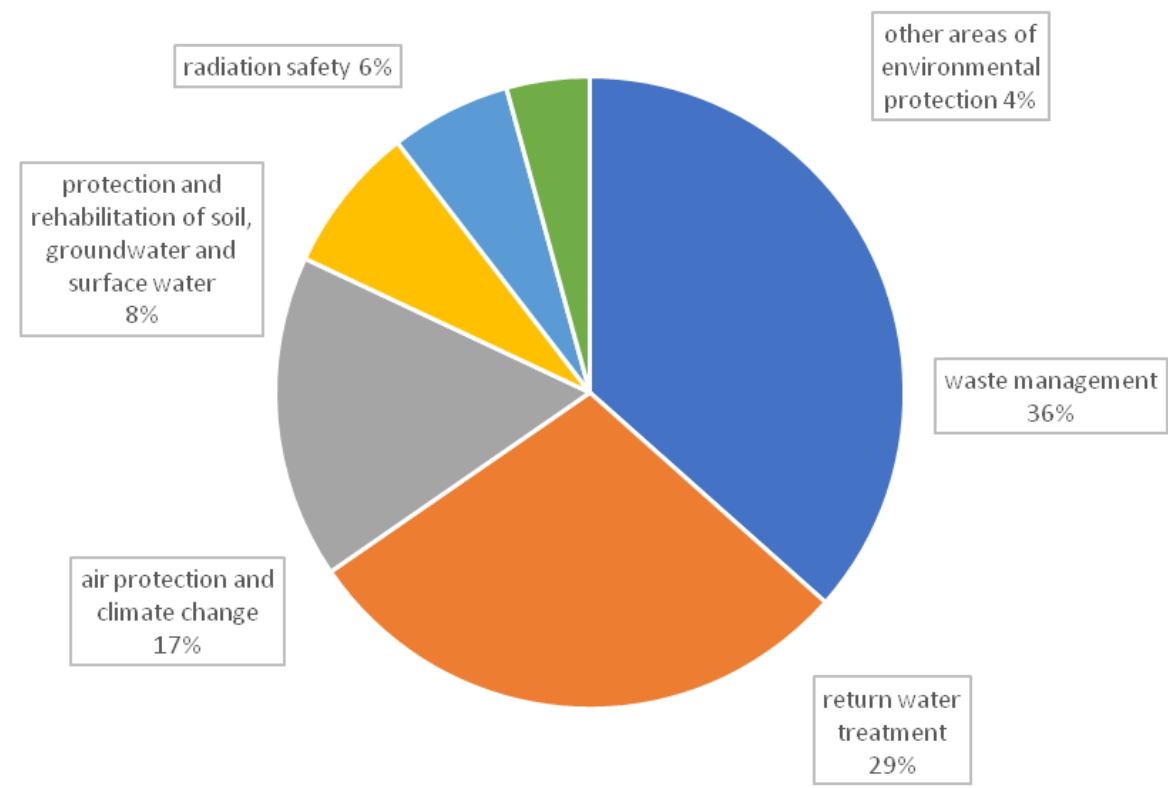

Fig. 4. Structure of expenditures on environmental protection by type of environmental protection measures in 2020

*built by the author on the basis of data [1]

As can be seen from the graph shown in Fig. 4, the largest shares of environmental costs are spent on waste disposal, water purification and air protection. This distribution is quite natural, given that these items of expenditure represent the greatest problems in this area.

So, for example, the problem of waste disposal is the most famous and popular not only among people professionally engaged in the study of environmental problems, but also among the rest of the population, since the importance of this problem is covered by marketers of almost all major brands, which in recent years has created a kind of "trend environmental friendliness". Water pollution issues are also part of the general problem of large amounts of waste, which in turn leads to air pollution. That is, it is important to understand that all the components are interconnected and, accordingly, the solution to the problem and the costs must be complex.

The main type of management of the amount of emissions and the state of the environment for the authorities is the environmental tax [12].

For example, in developed countries in Europe, emissions are regulated through an emissions trading system. In some cases, the plant can use tax incentives. As a rule, their receipt is associated with stimulating him to introduce "environmentally friendly" technologies or processes.

For example, in Italy, companies that use the latest technologies to reduce their negative impact on the environment can claim the so-called "hyperamortization" of these assets. What does it mean? In fact, a company can freeze up to $270 \%$ of the value of such an asset instead of $100 \%$.

In Belgium, the state can reimburse a significant part of tax costs (up to $80 \%$ ) if the company is a party to agreements on the implementation of the latest energy saving technologies (for example, in accordance with the ISO 50001 standard) [12].

The Ukrainian authorities are trying to keep their focus on the level of pollution on the issue of environmental tax, while the authorities of European countries are trying to tax energy carriers. So tax rates are divided by type of waste and hazard. The income received as a result of the collection of this tax is distributed $25 \%$ to rural and city budgets, $30 \%$ to regional and $45 \%$ to the state budget.

Consequently, research and development of environmental management, state and development is relevant today for the whole world and for Ukraine, especially given the negative forecasts of scientists and analysts. The choice of a strategy for managing economic costs at the micro level and political strategy at the macro level play a decisive role in the development and welfare of the country. This makes it necessary to determine an individual strategy for Ukraine, taking into account the country's characteristics. Since the main focus of developed countries today falls not only on maintaining economic development, but also on the development of the ecological sphere, then Ukraine, as a country striving to enter the European Union, needs to change its course to a more environmentally friendly one. As noted, industrial development, although it has a positive effect on the country's economy, but at the same time entails a significant deterioration in the ecological state, which in turn negatively affects the health of the population and the standard of living in general.

Therefore, to ensure sustainable development of Ukraine, it is necessary to carry out reforms in a comprehensive manner. Not preferring not only economic development, but also the improvement of the ecological state of the country. Since Ukraine is considered an agrarian country, and has all climatic conditions for the use of 
natural energy, which will significantly improve the standard of living of the population, because this is the main priority for the state.

\section{References}

1. State Statistics Service of Ukraine. URL: http://www.dneprstat.gov.ua/

2. Environmental safety in European countries: methods of economic regulation and experience for Ukraine. URL: http://ird.gov.ua/irdp/p20200038.pdf

3. Environmental safety of Ukraine. URL: http://www.philosophy.univ.kiev.ua/Files/Vykladachi/Hylko

4. VOX UKRAINE. URL: https://voxukraine.org/

5. MinFin. URL: https://index.minfin.com.ua/

6. EcoBusinessGroup. URL: https://ecolog-ua.com/

7. Environmental performance index. URL: https://epi.yale.edu

8. Eurostat. URL: https://ec.europa.eu/ eurostat/data/database

9. United nations. Environment statistics, Climate change statistics. URL: https://unstats.un.org/unsd/envstats/climatechange.cshtml

10. World Health Organization (WHO). URL: https://www.who.int/ua

11. Yeliseyeva O.K., Proshkina P.M. Assessment of the impact of environmental safety on the life quality of people. Materials of VI International scientific-practical conference. $2021.359 \mathrm{p}$.

12. Yeliseyeva O.K., Vasilieva O.O. Theoretical aspects of environmental taxation: domestic and foreign experience. Economics. Finance. Law. 2018. №10/1. P. 33-36.

Paper received : 18.10 .2021

Printed : 07.12 .2021 